\title{
FETICHISMO E REGRESSÃO MUSICAIS EM THEODOR ADORNO
}

\author{
Musical fetishism and regression in theodor adorno
}

Verlaine Freitas

UFMG

Resumo: O objetivo do artigo é fazer uma análise do texto "Sobre o caráter fetichista na música e a regressão da audição", de Theodor W. Adorno, mostrando como a noção de fetiche permite ao autor delinear a auto-negação da música, tanto pela absorção do valor de uso pelo de troca, quanto pela infantilização do público, momento em que a pseudo-atividade demonstra uma vertiginosa acoplagem entre indivíduo e sociedade.

Palavras-chave: Theodor Adorno; fetichismo musical; regressão da audição; cultura de massa

Abstract: The objective of the paper is to make an analysis of Theodor W. Adorno's text "On the fetishistic character in music and the regression of hearing", showing how the notion of fetish allows the author to delineate the self-denial of music, both by the absorption of value of use by the value of exchange, and by the infantilization of the public, when the pseudo-activity demonstrates a vertiginous coupling between individual and society.

Keywords: Theodor Adorno; musical fetishism; hearing regression; mass culture

O texto "Sobre o caráter fetichista na música e a regressão da audição" ${ }^{1}$, de Theodor Adorno, foi escrito como uma resposta ao artigo "A obra de arte na era de sua reprodutibilidade técnica" de Walter Benjamin e constitui, junto a outros textos da época, uma fase preparatória da Filosofia da nova música, texto fundamental das análises musicológicas do autor ${ }^{2}$. A polaridade entre a obra de arte aurática e a reproduzida mecanicamente, tal como vista por Benjamin, teria negligenciado a

\footnotetext{
${ }^{1}$ ADORNO, Theodor Wiesengrund. "Über den Fetischcharakter in der Musik und die Regression des Hörens". In: Dissonanzen. Einleitung in die Musiksoziologie. Gesammelte Schriften, Vol. 14, pp.14-50.

2 Cf. Adorno, "Wissenschaftliche Erfahrungen in Amerika". Kulturkritik und Gesellschaft I/II. In: Gesammelte Schriften. Vol. 10.2, pp.705; cf. também o prefácio da Filosofia da nova música.
} 
relação dialética entre os âmbitos da arte séria ${ }^{3}$ e da cultura de massa, considerando de forma estanque o que apresenta uma imbricação tensa e implica em uma mutabilidade histórica do próprio conceito de $a^{4} e^{4}$. Nesse ensaio, originalmente publicado em 1938, Adorno advoga uma importante perspectiva antropológica, tornada visível pelo modo como a audição da música é inserida no processo de racionalização ocidental. Antecipando conceitos e temas do importantíssimo capítulo "Indústria cultural. O esclarecimento como mistificação das massas" da Dialética do esclarecimento, faz uma análise significativa do que representa a extensão da racionalidade instrumental e capitalista à produção e audição musical, com implicações filosoficamente profundas na concepção da subjetividade contemporânea.

Nossa apresentação do texto visa ressaltar aspectos nodais referentes à conformação das mentalidades, de modo a contribuir à discussão do que significa a massificação do gosto para o indivíduo de nosso tempo.

\section{O fetichismo musical}

O conceito de fetiche que fundamenta as análises adornianas da música de massa provém, como já foi ressaltado pela tradição de comentários, não do emprego psicanalítico do termo, mas da crítica de Marx à mercadoria capitalista. O termo foi empregado pela primeira vez, de acordo com Alfonso lacono, por Charles de Brosses em sua obra Du culte des dieux fetiches, publicada em $1760^{5}$, denotando uma etapa da história da formação da consciência religiosa em que objetos, animais ou vegetais receberiam a atribuição de poderes sobrenaturais, malignos ou benignos. Esse sentido inicial permanece no famoso capítulo sobre o fetichismo da mercadoria de $O$ capital de Marx e se estende ao artigo de Adorno comentado por nós, pois em ambos os filósofos

\footnotetext{
${ }^{3} \mathrm{O}$ adjetivo "séria" (ernst) para a música, em Adorno, implica dizer que se trata de uma obra artística feita para audição concentrada, que pretende ser ouvida por si mesma, e não como fundo musical ou acompanhamento de outras atividades. Acima de tudo, porém, significa não oferecer ao ouvinte o prazer do divertimento, da distração ou do relaxamento, não sendo algo lúdico, esforçando-se em seguir uma lógica estrita de relação crítica com as obras e os estilos anteriores. A música de massa ainda pode ser considerada "séria" no que concerne à sua tarefa profissional de produção de um artefato tecnicamente bem realizado, mas tal esforço se dirige, ao fim e ao cabo, a uma audição dispersa, lúdica e alheia ao compromisso composicional da música normalmente designada como "erudita".

${ }^{4}$ Cf. Adorno: Ästhetische Theorie. Gesammelte Schriften. Vol. 7, p. 89.

${ }^{5}$ IACONO, Alfonso. Le Fétichisme: histoire d'un concept. Paris: Presses Universitaires de France, 1992, p.5.
} 
se trata de perceber como um objeto singular incorpora valores, significados e dimensões sociais comparáveis à transcendência sagrada, estabelecendo uma conexão direta, imediata e irrefletida entre a presença aqui e agora da coisa e um plano abstrato, difuso e pouco discernível pelo sujeito. De forma análoga a como os membros de uma civilização primitiva pensavam se apossar das forças sagradas e dirigi-las de acordo com seus desígnios por meio das técnicas da magia, o consumidor das mercadorias físicas e culturais toma-as como embebidas de um poder de representação que transcende suas qualidades utilitárias e musicais ${ }^{6}$. - A primeira metade do texto de Adorno dedica-se a mostrar a dinâmica social e individual dessa atitude fetichista.

\subsection{A falsidade do gosto, do particular e da totalidade musicais: a negação do indivíduo}

A música é marcada por uma ambiguidade afetiva: ao mesmo tempo em que incita emoções, é capaz de apaziguá-las, e isso define muito da dialética de progresso e regressão musicais no ocidente, já desde a antiguidade clássica grega. Em sintonia com o racionalismo platônico, alinhado ao princípio geral de civilização como fundada em uma racionalidade universalmente reconhecida, o nível da apreciação estética, ou seja, o gosto, é tomado como proporcional ao princípio de sublimação idealizada das paixões, momento em que a dispersão da particularidade dos afetos é percebida como decadência estética, musical e de cultura. O refinamento e cultivo do gosto seriam proporcionais à negação deste vínculo imediato, emotivo, somático com música: quanto maior a integração neste âmbito abstrato do reconhecimento universal, mais o indivíduo e a sociedade se reconhecem reciprocamente através da placidez sem arestas da música.

A categoria do gosto, porém, é inadequada para se refletir sobre a condição atual da música: tanto para a séria quanto para a de diversão. A primeira se mede muito mais por critérios cognitivos, vinculados à objetividade do estilo, da resolução dos problemas técnicos colocados pela linguagem e pelo material musical, e menos

\footnotetext{
${ }^{6}$ Apesar de o fetichismo concebido por Adorno derivar mais de Marx do que de Freud, é interessante investigar como o conceito de onipotência dos pensamentos, como falado em Totem e tabu, aproximase de forma instrutiva das reflexões adornianas.
} 
pelo conceito de prazer ou desprazer, centrado em uma subjetividade concebida como ponto de referência do juízo estético. A segunda, a música leve ou popular, caminha em direção ao outro extremo, na medida em que não é apreciada pela atitude judicativa do gosto, mas sim por diversos outros aspectos, como o do reconhecimento de tal música já ter sido ouvida anteriormente, ter composto a trilha sonora de algum filme, ter como autor alguém com um relato biográfico interessante etc. ${ }^{7}$

$\mathrm{Na}$ perspectiva de Adorno, a sociedade contemporânea assiste ao definhamento da própria categoria de sujeito, e a falência da capacidade de julgar a música por ela mesma é apenas uma consequência desse processo de dessubjetivação. Tal como é afirmado neste e em outros textos de sociologia musical do autor, o que é oferecido aos consumidores contém uma homogeneidade estético-musical que virtualmente impede toda possibilidade de escolha genuína, e a auto-percepção de gostar mais desta ou daquela música é superficial e ilusória.

A música leve fala para quem não é capaz de ouvi-la, reforçando essa inaptidão ao preencher de forma artificial os vazios deixados pela ausência de comunicação entre os indivíduos. Sendo percebida apenas como pano de fundo de tudo mais que se realiza, ela é uma espécie de fiadora para o desejo das pessoas de não precisar ouvir música, pois todos já se percebem musicalmente amparados por esta folhagem sonora que recobre o caminho cotidiano. Mesmo aquilo que the seria mais próprio, a diversão, é apenas prometida, sendo recusada no próprio ato perceptivo, uma vez que, sendo apenas um ingrediente de toda a experiência cotidiana, nunca vale por si mesma. A preocupação que os anunciantes dos intervalos comerciais sempre têm de suas peças publicitárias receberem muito pouca atenção é válida como leitura da atitude para com a própria música: ela é escutada, mas não ouvida, e mesmo quando o é, significa apenas uma outra dimensão da mesma realidade do ouvinte.

O discurso sobre a decadência do gosto ataca de forma não-dialética dois aspectos importantes para o conceito de progresso musical: a multiplicidade

\footnotetext{
${ }^{7}$ No ensaio "On popular music" faz uma apresentação didática e detalhada de tais aspectos envolvidos no reconhecimento da música popular. Cf. Adorno, "Sobre música popular". Tradução de Flávio R. Kothe. In: COHN, Gabriel. Theodor W. Adorno. São Paulo: Ática, 1986, pp.115-146.
} 
enfraquecedora e desviante do estímulo sensível e a preponderância da pessoa, do indivíduo, da singularidade sobre a totalidade representativa do âmbito social.

Em sua República, Platão condenava explicitamente todos os modos e instrumentos que não correspondiam ao reforço da postura ativa, viril e guerreira. Em vez de a cidade platônica construída segundo o lógos ser a utopia política que a história da filosofia concebeu, ela representa, na verdade, mecanismos de censura e de apologia da continuidade das relações de poder já estabelecidas, mas agora no registro do lógos, da razão. Está em jogo a necessidade de reafirmar o processo de integração sem resto do indivíduo na coletividade. O brilho e a dispersão dos momentos sensíveis, nesse contexto, representam uma etapa progressista de diferenciação do indivíduo como pessoa e da particularidade sensível em contraste com a totalidade da obra. As dimensões harmônica e colorística da música dependeram exatamente dessa consciência da concretude material dos sons, das diferenças timbrísticas, da multiplicidade e riqueza dos harmônicos. A consciência do papel do indivíduo em sua relativa autonomia diante do peso da coletividade contribuiu para a dessacralização da música (sua profanidade), conduzindo à consciência da autonomia do estético. Este somente se faz valer como tal quando a totalidade cósmico-coletiva não predetermina o sentido de toda a superfície sensível, musical. É precisamente por isso que a acusação de superficialidade (do gosto) é ao mesmo tempo equivocada e correta: engana-se em ver apenas o aspecto degenerativo referente a uma unidade elevada, sublime, mas acerta ao localizar precisamente o plano de realidade em que o estético-musical efetivamente encontra seu lugar de realização: a superfície sensível do som.

Essa progressividade na consciência do particular musical, porém, foi acompanhada do impulso para a síntese na música séria. A relação direta, imediata e absoluta com o atrativo sensível, como veremos mais à frente, constitui um dos principais aspectos da regressividade na música de massa. A unidade sintética, sintetizada, é a que institui uma aparência de felicidade socialmente compartilhada em que o gosto e o gozo com a dispersão sensível não sejam mera aparência impotente e fugidia (ou seja, uma ilusão). Em contraste com a unidade cósmico-coletiva 
radicalmente imposta às particularidades, a síntese estética é conseguida em um equilíbrio eternamente instável para com o que é múltiplo, situando-se em um ponto de fuga não localizável positivamente. A obra A flauta mágica, de Mozart, constitui para Adorno a última em que se conseguiu um equilíbrio pleno entre a exigência forte de uma síntese e a fruição dos elementos sensíveis em sua concretude menos mediata.

$\mathrm{Na}$ industrialização da cultura do capitalismo tardio, o estímulo, a subjetividade e a secularização deixam de ser componentes progressivos, passando a ser parte da regressão estética. Se outrora eles atentavam contra uma totalidade cósmico-coletiva preestabelecida, agora trabalham a favor de outra, orquestrada por meio da maquinaria capitalista, que vende o pertencimento a ela própria pela conexão imediata à multiplicidade glamorosa de cada apelo sensível, corporal, emotivo (daí Adorno dizer que o consumidor é apanhado na linha de sua menor resistência). Antes, a totalidade era estática (vinculada à tradição da nobreza guerreira) e a multiplicidade subjetivamente percebida era crítica (pelo impulso libertário do indivíduo); agora, esta última tem o papel diversionista de anular a perspectiva crítica, que se associa, por sua vez, precisamente à totalidade sintética conseguida pelas grandes obras de arte. Ao contrário do todo social, que, segundo Adorno, vive da manutenção de suas contradições internas inexpugnáveis (uma totalidade cindida), o estético tem seu sentido precisamente na crítica a essa reconciliação ilusória, forçada, das disparidades.

Tudo isso caracteriza a audição atomizada ou atomística, em que os elementos individuais perdem sua força própria precisamente pelo fato de se desconectarem do que poderia lhes conferir um significado progressista, para além da eterna repetição de um gozo instantâneo, marcado pela necessidade de reafirmar valores sociais preestabelecidos. Em vez da contraposição entre uma multiplicidade díspar e uma totalidade crítica, que supere dialeticamente as tensões internas de seus componentes, temos um esquema geral de percepção, de mentalidade e de racionalidade que destrói ambos os polos constitutivos da dialética de instauração do 
significado estético propriamente dito $^{8}$. O prazer somente é legítimo (verdadeiro) na arte ao se mesclar à sua renúncia, à abdicação de um gozo culinário imediato ${ }^{9}$. Se antes, na vertente platônica, a ascese musical era índice de empobrecimento estético, posto que anulava a multiplicidade dos materiais sensíveis, na arte moderna ela é índice de progresso, de enriquecimento, retirando dos particulares sua imediatidade a ser consumida. O valor "espiritual" do estético se degrada quando não mais habita a totalidade das obras, quando quer ser experimentado no brilho, na cor e no glamour de cada particular.

O gozo atomizado da cultura de massa é uma antecipação fraudulenta de uma felicidade inalcançável por princípio, estabelecendo-se em sua parcialidade perversa e "patológica", no sentido de reafirmar indefinidamente a falsidade auto-derrogatória da ânsia pela completude de sentido do objeto de desejo. Embora mesmo na música mais comercial o particular continue a existir, ele está impregnado do brilho e do glamour dos valores e significados sociais apreendidos de forma difusa, não muito específica, que se sedimentam em cada acorde, em cada refrão, em cada agudo estridente ou baixo profundo. Essa transcendência - o fato de o particular não ser ele mesmo - qualifica a aparência estética. Todo o problema do gozo atomizado consiste na necessidade dessa mediação. O prazer corporal, sensível, sexual, possui toda sua realidade e é obviamente legítimo: desde que não necessite dessa aparência de transcendência, pois então será marcado pela falsidade constitutiva de toda aparência. O fato de mesmo a obra de arte mais avançada e crítica não poder renunciar a este caráter de aparência constitui um capítulo específico e importante da teoria estética de Adorno.

De forma análoga a como a categoria de gosto não se aplica nem à música contemporânea nem à de massa, tampouco a de fruição estética o faz. Em ambos os polos musicais, por motivos opostos, a realidade concreta do prazer como algo que

\footnotetext{
${ }^{8}$ Essa relação entre um esquema geral de percepção e o detalhe percebido em seu isolamento pauta grande parte dos argumentos de Adorno e Horkheimer sobre a indústria cultural na Dialética do esclarecimento.

9 "A estética que não se move na perspectiva da verdade esmorece perante sua tarefa; no mais das vezes, é culinária". Adorno, Ästhetische Theorie: Frühe Einleitung. Gesammelte Schriften, Vol. 7, pp. 515516. (Todas as traduções de textos de Adorno citados diretamente são de nossa autoria.)
} 
vale por si está ausente, pois toda fruição é radicalmente mediada por outros fatores.

O pseudo-prazer, característico do consumo da música de cultura de massa, é uma fase tardia do que representou a alegria individual em contraste com a sobriedade da nobreza feudal. Outrora, a experiência pessoal da melodia cantada ou assobiada significou o gozo simbolicamente real da individualidade afirmando-se em sua diferença perante a totalidade social. No capitalismo tardio, quando a experiência de ser burguês se alastrou por toda uma sociedade ela mesma atomizada, esse prazer passou a ser sorvido como uma espécie de souvenir, um adesivo ostentado para continuamente reafirmarmos a nós mesmos em nosso estatuto de pessoa. A universalização do princípio da individualidade burguesa no capitalismo tardio - em que a liberdade mostrou-se muito mais uma imagem do que uma realidade caracteriza-a como cópia de si mesma, uma falsificação sistematicamente planejada e vendida em pequenas doses para preencher o vazio deixado pela ausência do trabalho - reafirmando, mais uma vez, o silêncio que marca tanto a impossibilidade de fala quanto da audição.

Na relação entre música séria e música leve, é necessário evitar tanto a passagem contínua, sem salto, entre uma e outra, quanto também uma ruptura total, como se ambas coexistissem lado a lado sem se influenciarem reciprocamente. Todo o esforço de Adorno consistirá em mostrar que esses dois polos da produção musical refletem uma condição essencial do capitalismo tardio, a saber, de uma totalidade cindida, fraturada ${ }^{10}$, que mostra sua racionalidade precisamente no modo como escamoteia, dissimula, obscurece, as contradições que lhe dão suporte e constituem o fundamento de sua continuidade. A música séria é em grande medida determinada por negar o que a indústria cultural falsamente promete, de modo que sua recusa do divertimento e do prazer lúdico é, de certa forma, algo reativo, não imediatamente oriundo de uma necessidade interna de sua articulação. A exigência radical de uma racionalidade autônoma e própria não subsiste como algo desconectado da realidade em que ela se realiza efetivamente: toda autonomia é sempre relativa, e não absoluta.

10 Essa ideia de uma totalidade cindida foi muito bem exposta por Deborah Cook no texto "The sundered totality: Adorno's Freudo-Marxist Paradigm". In: The culture industry revisited: Adorno on mass culture. Boston: Rowman \& Littlefield, 1996, pp.1-26. 
Por outro lado, não se passa da música leve para a séria através de uma gradação pedagógica, em virtude do fato de a primeira ser definida por uma racionalidade própria, tendo um sentido específico em se dar a conhecer como um prazer consumado, e não como etapa preparatória para outros modos de apreciação complementares e aperfeiçoados $^{11}$.

O contraste absoluto - e portanto falso - entre a cultura erudita e a popular nutre-se tanto de um eterno lamento pela distância da primeira em relação à realidade cotidiana, quanto de uma caracterização ideológica da segunda como algo natural, espontâneo. Ao contrário disso, é necessário compreender que o caráter hermético da música séria implica em uma proximidade objetiva e, portanto, verdadeira, para com o que os seres humanos possuem de melhor em si mesmos, ao passo que a proximidade supostamente natural da música leve é índice da alienação e distanciamento do indivíduo em relação a si próprio. A apreciação musical é sempre historicamente marcada: o gosto e o prazer das massas com a música leve não é um dado a se usar como fundamento explicativo para essa realidade estética, pois precisa, ele mesmo, ser explicado, é também um resultado histórico da realidade do capitalismo tardio ${ }^{12}$. Cada música de sucesso significa o quão bem sucedida é a articulação global da indústria da cultura em manter as massas em uma mentalidade a que são destinadas pelo trabalho alienado.

O destino do gosto e da fruição é o mesmo do "indivíduo": a ele não se reserva um espaço privilegiado nem na música séria nem na de massa. Em ambos os casos, por motivos opostos, a individualidade não se exerce em sua diferença substantiva, em sua autonomia e fim próprio. Na música séria, ao indivíduo se exige tanta concentração, disponibilidade para co-realizar a objetividade estético-musical e

\footnotetext{
${ }^{11}$ Essa recusa de a música de massa ser uma etapa para a erudita espelha o princípio mais amplo da crítica cultural de Adorno de a semicultura não ser uma passagem para a cultura em sentido próprio. Cf. Adorno, "Theorie der Halbbildung". In: Soziologische Schriften I: Gesammelte Schriften, Vol. 8, p.93-121.

12 Essa ideia é expressa de forma clara no capítulo "Indústria cultural" da Dialética do esclarecimento: "A atitude do público, que pretensa e factualmente favorece o sistema da indústria cultural, é uma parte do sistema, e não sua desculpa". "Kulturindustrie. Aufklärung als Massenbetrug". Dialektik der Aufklärung. Gesammelte Schriften, p. 143.
} 
suspensão de seus desejos imediatos, que dele pouco resta no sentido tradicional ${ }^{13}$. Na de massa, ao indivíduo se vendem (no sentido literal e metafórico) tantos atrativos sensíveis, que ele acaba abdicando de si por ser subornado a aderir ao que a moda e o espírito mercantilizado propagandeiam como sendo próprio da individualidade de seu tempo: o indivíduo nunca "é", pois dele se exige o tempo todo que se atualize, atue como portador de valores flutuantes ${ }^{14}$.

\subsection{O alastramento vertiginoso do fetiche musical}

Tudo na música pode se transformar em objeto de fetiche, desde o puro som até o ato de ligar o rádio, passando pela marca ou data de fabricação de um instrumento, um simples motivo melódico, o fato de se possuir uma voz bonita (independente do talento para cantar), certas peças musicais de um autor em detrimento de outras (sem conexão com a diferença de nível estético-musical). Em todos esses casos, ocorre o fenômeno de que cada vez menos a coisa vale por ela mesma, inserindo-se em um sistema macro de manipulação, trânsito e mescla de valores em que tudo se torna tendencialmente substituível por qualquer outra coisa, até mesmo por si próprio, pois a auto-percepção de se vincular a alguma coisa substitui o prazer concreto com esta última.

Dentre as várias implicações disso, uma das mais importantes é que mesmo a música séria não está, de forma alguma, isenta de ser apropriada de forma falsa ${ }^{15}$. Até a diferença entre música séria e leve torna-se um fetiche, pois é utilizada com o propósito de mascarar o fato de que, apresentadas em num mesmo contexto musical, uma música séria e outra de cultura de massa não possuem diferenças quanto a seu

\footnotetext{
${ }^{13}$ Igual posicionamento é colocado por Adorno em sua tipologia dos ouvintes musicais, quando diz que o expert necessita de um processo formativo tão estrito e rigoroso que muito de sua liberdade se perde ao seguir a demanda objetiva da música. Em virtude disso, o tipo imediatamente inferior, o "bom ouvinte" seria até mesmo melhor, considerado em sua condição humana como indivíduo. Cf. "Typen musikalischen Verhaltens". In: Dissonanzen. Einleitung in die Musiksoziologie. Gesammelte Schriften, Vol. 14, pp.182-183.

14 Uma ideia semelhante será exposta muito tempo depois por Zygmunt Bauman, ao dizer que a individualidade contemporânea é pautada por ser uma tarefa indefinidamente reafirmada, em que cada pessoa é instigada a se fazer, a se produzir incessantemente. Cf. Bauman, Modernidade líquida. Tradução de Plinio Dentzien. Rio de Janeiro: Zahar, 2001, p.40.

${ }^{15}$ Sobre a relação do conceito de fetiche com a música séria, cf. Vladimir Safatle, "Fetichismo e mímesis na filosofia da música adorniana". Revista Discurso, no. 37, 2007, pp.365-406.
} 
valor estético-musical para o ouvinte-consumidor. No caso da música leve feita para se tornar um sucesso, isso se torna enfaticamente perceptível por se ratificar o fato de ela ter feito sucesso, e não a própria música. O prazer de ingressar no universo dos que produziram esse sucesso usurpa a satisfação com a própria obra. O princípio de idolatria das estrelas de cinema, cujo nome nos cartazes é mais relevante do que o próprio título do filme, alastra-se por toda a produção musical; isso vale para diversas peças da música séria: a quinta e a nona sinfonias de Beethoven são costumeiramente mais admiradas que as outras, sem apoio suficiente em aspectos estético-musicais para tal predileção.

Um dos vícios favorecedores dessa audição fetichizada é o apego a frases melódicas facilmente memorizáveis, transpondo à audição da música séria a atitude atomizada típica da cultura de massa. Tal como um sorriso ou um cabelo bonito é a marca distintiva e propriedade de uma estrela de cinema, uma ideia melódica é percebida e consumida como a propriedade de seu autor, um objeto a se tomar emprestado e levar para casa, de forma análoga a como se apropria de um pôster ou um modo de falar ou de vestir de grandes personalidades. Essa crítica não significa negar a importância da melodia na música séria, mas sim dizer que ela está submetida, tal como todos os outros elementos, à percepção de conjunto: o problema a ser atacado não é a melodia em si, mas sim seu isolamento em relação a tudo mais que poderia conferir a ela sua importância relativa, e não absoluta.

As vozes de cantoras e cantores são o caso mais drástico de fetichismo, obedecendo à lógica de anulação da concretude da coisa. Se antes a admiração era dirigida ao virtuosismo vocal, aos poucos a atenção se desloca simplesmente para a dimensão material de se ter uma voz potentemente aguda ou profundamente grave, quase sem relação com a habilidade de cantar. O que importa nuclearmente em termos estético-musicais, a capacidade de interpretação viva e correta da partitura, por sua vez, nem mesmo depende do brilho e do virtuosismo vocal, da mesma forma que uma peça de piano, para ser bem executada, não necessita da qualidade soberba de um Bösendorfer. O mesmo ímpeto fetichista vale para instrumentos famosos, como 
o Stradivarius. A mera relação idealizada com o passado que se consubstancia no instrumento substitui a relação efetivamente relevante: com a música.

Em todos esses casos, em que os momentos estimulantes da ideia melódica, da voz e do instrumento são idolatrados, temos um distanciamento irracional e inconsistente para com o plano estético-musical, e isso afeta a própria concretude do foco de atenção: tal é o esquema perceptivo fundamentador de toda atitude de consumo com as músicas de sucesso na cultura de massa, quando a obra se torna tãosomente um campo de possibilidades de investimento fetichizado do que ocorre em seu interior.

Como dissemos ao início, Adorno emprega o conceito de fetiche baseando-se na conceituação marxista do fetichismo da mercadoria. O princípio geral dessa concepção, tal como se tornou clássico já a partir do texto Para a crítica da economia política, é que o valor de troca de um produto é determinado pela quantidade social média de trabalho requerido para produzi-lo. O que faz a mercadoria valer, ao ser comprada e vendida, é uma dimensão social, histórica, cultural, e é isso que é propriamente trocado através da coisa-mercadoria. O vínculo "psicológico", empírico, pessoal, com mercadoria, entretanto, focaliza a dimensão objetiva, material, momento em que a relação fetichista se mostra com toda força ${ }^{16}$. O valor de troca, porém, devido a sua abstração e maleabilidade (capaz de agregar diversos outros valores, como status, juventude, família etc.), pode ser chamado de "valor de representação", ao ampliarmos o leque de elementos a compor a atratividade da mercadoria (utilitária ou cultural).

Nas mercadorias culturais, que não possuem um valor de uso tão explicitamente determinado como os demais produtos, o valor de troca acaba por absorver (e substituir) toda a dimensão concreta na relação com a coisa-música. Esta serve como pretexto, passaporte e veículo para relações financeiras e de absorção de uma quantidade indefinidamente grande de valores, eles mesmos por demais indefinidos, sendo um deles a capacidade de uma determinada música em gerar

${ }^{16}$ Cf. MARX, Karl. "Der Fetisch-Charakter der Ware und sein Geheimnis". In: Das Kapital. Stuttgart: Kröner, 2011. 
recursos com sua venda, levando o consumidor a adquirir a satisfação de contribuir para o sucesso capitalista do investimento na produção artística. O âmbito musical de massa propagandeia a si mesmo, serve-se dos mecanismos de circulação de mercadorias e valores para afirmar-se tautologicamente: o concerto ao vivo é oferecido de graça para que o disco das músicas seja comprado; se este já o foi, serve de incentivo para ir a outro concerto que oferecerá músicas do próximo disco etc.

O aspecto sublime e culturalmente elevado das mercadorias culturais, especialmente da música, fornece-Ihes a aparência de estarem isentas dos mecanismos que atravessam o sistema de compra e venda capitalista. A música aparece como culturalmente "elevada demais" para poder ser confundida com coisasmercadorias: é precisamente por isso que a mercadoria musical se presta a ter seu valor de uso completamente tragado pela abstração do valor de troca. O caráter por assim dizer delgado e tênue da coisa-música torna-a especialmente permeável ao fluxo de valores veiculados socialmente, de modo que, em vez do amálgama de valor de uso e valor de troca, inerente a toda mercadoria concreta, no limite tem-se apenas o de troca. A mercadoria cultural se mostra como imediatamente usufruível, como algo de que se pode apropriar emocional e racionalmente no puro contato com sua realidade visual, sonora, emotiva e temporal. Essa aparência, porém, é ilusória, pois o valor de uso da coisa-música é "capturado" imediatamente pela mediação por excelência no capitalismo: o valor de troca, o plano da circulação de valores sociais, que arrasta para si todo o investimento afetivo na materialidade da música.

\subsection{A fusão entre indivíduo e sociedade}

Uma vez que a sociedade do capitalismo tardio perdeu a âncora simbólica forte das religiões objetivas, das tradições e da unidade feudal, tornando-se atomizada e dispersa em um individualismo acachapante ${ }^{17}$, tornou-se necessário conceber e explicar em que consiste a força de coesão das mentalidades. Para Adorno, o cimento social, agora, é fornecido pela cultura de massa, e a música se presta especialmente bem a essa função. O princípio geral é de transpor a singularidade simbolicamente

\footnotetext{
${ }^{17}$ Esse complexo foi muito bem delineado por Zygmunt Bauman em Modernidade líquida.
} 
concreta com a coisa - que individualiza as pessoas - para o âmbito socialmente abstrato de valores cuja dinâmica consiste propriamente no "tomar parte", estar integrado, saber do que se trata, estar atualizado. Todos os consumidores passam a idolatrar a sublimidade inatingível do próprio sistema em sua totalidade - servindo a ela, sendo-Ihe obediente - , tornando-se, então, escravos e proletários empobrecidos de um mega-sistema que se robustece precisamente vendendo o gozo de se poder participar em sua grandiosidade ${ }^{18}$. Nesse círculo vicioso de auto-reforço, toda a concretude do prazer é subversiva, devendo ser deslocada e tendencialmente substituída por níveis abstratos e postergados de prazer, por satisfações vicárias, parciais, em doses homeopáticas e que dispensam sistematicamente o gozo da reflexão sobre suas próprias motivações.

Todos os meios, ações, comportamentos e atitudes do dia-a-dia que servem a um propósito obtêm do valor de troca uma dignificação, uma importância e um papel que jamais teriam. A compra de um carro, por exemplo, nunca seria vista como tão importante pelos homens caso esse objeto fosse medido essencialmente por sua utilidade, por sua dimensão material concreta. Somente como passaporte para valores de troca abstratos o uso dos veículos se torna "magicamente" significativo em termos sociais. Enquanto a relação simbolicamente concreta com os objetos de uso individualiza, permite certa autoconsciência do que nos define no âmbito de nossos gostos, preferências e recusas, o valor de troca tende a homogeneizar a todos, tende a dissolver as particularidades simbólicas no tráfico de valores abstratos servidos ao sabor da moda, das contingências históricas, elas mesmas desprovidas de singularidade simbólica.

Outra questão reside no fato de que, quanto mais o valor de troca absorve o valor de uso, quanto mais a materialidade concreta cede lugar à mobilidade abstrata e multifacetada do valor de troca, quanto mais este se torna o único foco de investimento afetivo, paradoxalmente ele mesmo sai de cena, em virtude do fato de consistir precisamente em formas de deslocamento da afetividade, do interesse.

\footnotetext{
18 Jean Baudrillard reafirma essa característica quando diz do consumidor como um funcionário do consumo. Cf. A sociedade de consumo. Tradução de Artur Morão. Porto: Elfos, 1988.
} 
Qualquer coisa que se ofereça com um mínimo de concretude, ditado pela moda, por valores de ocasião, tendências esporádicas etc., pode servir como um ímã que atrai as atenções do consumidor. No limite, o valor de troca é um não-lugar que funciona meramente como uma areia movediça a desfazer pontos de fixação do trabalho simbólico, do esforço subjetivo, da construção cultural, da atenção dirigida etc. Por isso ele está na iminência de ser engolido por essa sua própria não-substância, tornando-se refém de seu caráter hiperbolicamente diversionista. ${ }^{19}$

A identificação do indivíduo com o sistema cultural se dá de forma sadomasoquista, em virtude da acachapante orquestração homogeneizadora dos produtos oferecidos ao consumo. Na proporção em que todas as coisas seguem padrões e estereótipos semelhantes, "gostar" equivale ao prazer de anular (masoquistamente) a si mesmo como quem seria capaz de uma escolha refletida e genuína. Tal como na concepção psicanalítica de identificação com o agressor, em que se pratica em relação a si o que se recusava do outro ${ }^{20}$, no sistema de consumo cultural o gosto com a música é apenas uma estratégia de sub-repção, pois seu verdadeiro objeto é a adaptação resignada ao que não oferece possibilidades substantivas de escolha.

Tendo em vista certo otimismo teórico relativo ao que cada ser humano é mais profundamente em si mesmo, Adorno não economiza esforços para demonstrar que o fato de as pessoas desejarem as mercadorias culturais advém de uma necessidade imposta externamente. Todo o mecanismo é elucidado a partir da ideia de uma identificação sem saída dos consumidores ao que lhes é oferecido na propaganda, como meio de obter o ganho pulsional de acomodação masoquista a determinado valor como sendo sua própria causa e seu próprio desejo. - Tal como a propaganda vive da insistência com que se imprime na mente dos consumidores através de repetição incessante, criando as diversas camadas cognitivas, desde a atenção mais firme até uma vaga lembrança, assim também as músicas o fazem.

19 Essa nossa leitura do valor de troca em Adorno baseia-se na concepção do consumo de Jean Baudrillard exposta no livro citado anteriormente, que faz uso do conceito de signo como princípio ampliador da noção de valor de troca.

${ }^{20}$ Esse conceito foi explorado por Anna Freud em seu famoso texto O eu e os mecanismos de defesa. 
Essa concepção de Adorno tem o seu lado forte e o fraco. O primeiro evidencia-se quando vemos que as diferenças de valor estético-artístico entre as produções oferecidas ao público devem ser pensadas no registro macro da vida no capitalismo. Nunca se ouve apenas e tão-somente uma música, pois a relação com qualquer sequência musical envolve necessidades psíquicas, emocionais, políticas, culturais em sentido amplo, e outras mais específicas, como o desejo de expressão da própria juventude ou maturidade, identificação de gênero, de opção sexual e infinitas outras. Em virtude disso, a "verdade" da diferença estritamente musical é dissolvida em uma "mentira" nos diversos outros registros que pautam, inapelável e necessariamente, o desejo pela música, uma produção estética ligada tanto à imediatidade evocativa das pulsões, quanto ao caráter sublime e elevado da cultura. Nessa transposição, as diferenças no primeiro plano tornam-se tanto mais falsas quanto reais, pois se afirmam como um excelente álibi para a integração dos indivíduos no complexo de valores vendidos, literal e metaforicamente, em todos os produtos.

A fraqueza dessa construção teórica, por outro lado, reside no fato de submergir todo o sentido motivacional dos indivíduos nas linhas de força macro da sociedade. Por mais que seja correto dizer das diferenças musicais como se inserindo em uma homogeneidade de valores sociais, não estamos autorizados a anular a importância da diversidade dos significados psíquicos, subjetivos, para cada pessoa. Fazer isso significa decretar, de antemão, a onipotência do sistema, recusando a tarefa crítica de conceber a possibilidade de alteração do status quo. Comparar o consumidor a um escravo que ama suas algemas significa duplicar no âmbito de uma teoria crítica aquilo que o sistema já faz com cada um de seus membros individuais. Tal como se sabe, uma das características de todo poder é o de se dar a conhecer como mais potente do que é na realidade, e aparentemente a teoria crítica sucumbiu a essa aparência. Ao mesmo tempo em que retiramos dos indivíduos, no plano teórico, a responsabilidade por suas escolhas de valores, anulamos no plano prático a viabilidade de uma ação política eficaz: por menor que esta seja, sucumbimos à ideologia ao reduzi-la a zero. 


\subsection{A anulação da música fetichizada}

As obras produzidas no espírito fetichista são afetadas tanto por seu desgaste devido à repetição incessante, quanto em sua própria constituição interna. Elas não apenas se apresentam como uma coletânea de ideias melódicas dispersas, quanto são apropriadas de forma hiper-romântica, ou seja, através de um investimento afetivo hipertrofiado, fazendo cada célula musical ressoar uma ideia ou ideal subjetivo. Não se trata, porém, de uma concepção expressionista, em que o sujeito teria seus elementos inconscientes traduzidos por meio da objetividade estética, mas sim de um curtocircuito entre a idealização individualista socialmente concebida e os elementos particulares da obra tornados escravos desta pressão domesticadora. A obra é desmembrada em todos os elementos que possam fazer o todo desprezível e o produto, um veículo dócil à manipulação e ao consumo pessoal. Ao se apropriar intimamente de um fragmento de uma obra, assoviando um trecho de uma sinfonia de Beethoven, por exemplo, a pessoa somente se relaciona com o que resta dessa composição depois de ela deixar de ser música, depois de não mais constituir uma totalidade dotada de sentido: este é substituído pelo prazer de romper a intimidade enigmática de seu ser-música.

Na medida, porém, em que a obra é reduzida a um mero fetiche, até mesmo este é ameaçado em sua existência minimamente concreta, e então é necessário injetar sistematicamente doses exógenas de espontaneidade, diferenciação, "estilo" etc. Quanto mais depravada a cultura, mais ela precisa de depravação para esconder essa sua mesma característica: a subjetividade reificada é usada em doses crescentes para contrariar a ausência de subjetividade, ou seja, de sua própria reificação.

Bastante característica da reificação e da depravação da música para o consumo é a prática do arranjo. Em termos concretos, há dois elementos que a caracterizam: manipulação e domesticação do tempo, através do recorte de motivos, temas e unidades melódicas e seu posicionamento em novos contextos; em segundo lugar, o arranjo é feito em função da colorística, ou seja, em nome tanto da simplicidade quanto da pretensa riqueza dos timbres, seja com o pretexto de tornar a execução mais barata, seja para "corrigir" a pobreza colorística de grandes obras do 
passado. Essa suposta pobreza dos clássicos, na verdade, origina-se da consciência forte do princípio construtivo, que submete o elemento singular à percepção de o todo se nutrir essencialmente de uma racionalidade pautada pela coesão de todos os particulares. Em virtude disso, a emergência concreta de elementos colorísticos, melódicos e cromáticos ganha toda a ênfase e força expressiva possível.

A prática do arranjo tem um princípio próprio: tornar tudo o que é ouvido capaz de apropriação individual, fazendo a lógica musical homogênea à da autopercepção individual. Para isso, cada elemento da música deve sofrer alguma espécie de intervenção, traduzindo-o para o ouvido já reificado: nada deve ficar isento do desejo de transformação, no mesmo instante em que a base estruturante, tanto da realidade social, quanto da música, não é atingida, nem compreendida. Esse estado de coisas localiza o que Adorno chama de pseudo-atividade: atuação frenética relativa a todo percebido, quando o movimento se contenta narcisistamente com sua própria hiperatividade, desviando o olhar da intervenção nos fundamentos histórico-sociais da realidade, seja ela a social, seja a da própria música. Isso aponta para uma ambivalência de interesse psicanalítico, a saber, que o objeto de respeito é também alvo de escárnio.

Deve-se localizar a prática do arranjo no contexto da diferenciação burguesa entre alta e baixa cultura. O burguês sempre foi aquele marcado pela mobilidade instável e insatisfeita consigo mesma, índice da precariedade de status de uma classe eternamente em ascensão, embora consciente de sua condição estática real, quando comparada à da alta burguesia. $\mathrm{O}$ arranjo quer dar ao burguês a consciência tranquila, não-culpada, de gostar de lixo cultural, sem o reconhecer e assumir explicitamente. 0 refinamento dos arranjos marca a dimensão kitsch de toda a obra cultural decadente: embelezar e conferir um caráter glamoroso ao que já dispensou a seriedade compositiva da instauração de uma racionalidade estética própria.

O fetichismo, porém, alcança a própria música séria, mesmo quando se distancia da diversão pretensamente elevada. Nesse momento, a fidelidade pétrea, rígida, ao que a obra deve ser "em si" mostra-se como uma formação reativa à barbárie da apropriação depravadora. Nesse mesmo passo, porém, ela é signo de 
barbárie, pois a suposta objetividade absoluta da música retira dela seu caráter vivo, contraditório, instável, humano, idolatrando a coisa como imagem dela mesma. Dispensando-se de assimilar a contingência humana e interpretativa da partitura, cada execução iguala-se à sua própria cópia eletrônica, anulando a contingência do decurso temporal pelo supremo esforço de ser totalmente fiel a seu preenchimento sonoro. Se a música tem a ver com a intimidade da consciência temporal subjetiva, a execução absolutamente sem lacunas impede o esforço da audição produtiva, tornando o sujeito tão repetitivo da coisa, quanto ela é de si mesma. Todo o aparato da apresentação musical usurpa a dignidade da própria música, eliminando as diferenças entre o plano da partitura, da orquestração, da interpretação, da audição e da leitura subjetiva.

O regente da orquestra fetichizada concretiza este ideal de enrijecimento interpretativo: ele normaliza de tal forma a execução, absorvendo em sua própria figura a tarefa de condução dos instrumentos, que no limite ele mesmo pode ser dispensado, pois o adestramento terá sido radical, não sendo mais necessária sua intermediação concreta, material, corpórea, sensível.

A relação entre audição regressiva e música fetichista é a de acomodação geral de todos os planos. Por outro lado, cada particular é tão cego em relação a suas motivações socialmente condicionadas, que toda pesquisa empírica sobre preferência musical é insuficiente em dois aspectos: primeiro, todo questionamento será respondido com aquilo que apenas confirma o que a indústria foi capaz de produzir nas mentalidades; por outro lado, o otimismo de uma pergunta como: "de que música você gosta?", que pretende esclarecer o próprio mecanismo da predileção, coloca em funcionamento toda a maquinaria social geradora dessa predileção. Esse tipo de pesquisa está baseado em uma concepção ilusória de relação biunívoca entre produto cultural e recepção, procurando estabelecer vínculos entre causa e efeito pontuais e específicos, ao passo que se trata, na verdade, de conceber tudo como engrenagens bem ajustadas a um sistema cuja lógica impera sobre todas as suas partes. Produção e consumo não podem ser compreendidos na relação entre elementos individuais, mas sim em sua totalidade de correspondência. 
Essa acoplagem resulta, no plano subjetivo, na virtual impossibilidade de cada indivíduo ser especificamente influenciado por este ou aquele produto. Em vez de produzir mentalidades específicas, o sistema reproduz a si mesmo através de infinitos mecanismos, dentre os quais um não pouco relevante é a manutenção da aparência de individualidade, diferenciação, senso crítico etc. Outra consequência é a percepção individual do valor prático de se ajustar às possibilidades de fruição oferecidas pelo mercado cultural. Ao longo de suas vidas, os indivíduos são sistematicamente convencidos de sua sociabilidade depender fortemente de sua disponibilidade para com o gosto médio de todos seus amigos, colegas de trabalho, namoradas e namorados, maridos e esposas, filhos etc. Quanto maior a recusa de jogar o jogo do gosto preestabelecido, maior é o risco de exclusão social.

\section{A regressão auditiva}

A contraparte do fetichismo na música é a regressão auditiva. Não se trata de um retrocesso a fases de desenvolvimento psíquico anteriores, embora se possa dizer de um infantilismo das massas. O que é regressivo, propriamente falando, é a sistemática negação do novo, do diferente, do que poderia ultrapassar o estágio atual das massas. Se, por um lado, desde sempre a maioria da população esteve excluída do conhecimento mais avançado da música, agora esse conhecimento não apenas inexiste, quanto é impedido pela lógica da audição atomizada e fetichista. Em vez de uma incultura musical, tem-se uma pseudo-cultura, fazendo com que quanto mais as mercadorias musicais sejam difundidas, mais a mentalidade dominante se agarra a tais produtos como meio para se defender de um progresso auditivo. Esse é o argumento principal: quanto maior a intimidade pseudo-cultural com as músicas, mais estranhos serão o projeto e a realidade do esteticamente diferente, e nesse momento a fixidez é índice de regressão. O infantilismo não significa um desenvolvimento precário (uma audição "infantil", ingênua), mas sim uma determinação neurótica de impedir qualquer avanço (uma audição pueril, infantilizada). O novo não é mais um objeto de desconhecimento ou de curiosidade, mas de ódio, de ressentimento, pois é tomado como uma afronta, um escárnio e uma prepotência para como o desejo masoquista de 
permanecer limitado ao que é oferecido como única alternativa. - O infantil em sentido forte, simbolizado como momento da felicidade, é ao mesmo tempo desejado e marcado com o selo da impossibilidade constitutiva, de tal forma que a consequência é de escarnecer do próprio desejo de felicidade.

\section{A audição pueril}

A música composta por detalhes não mediados pela totalidade somente é suportada por uma audição dispersa, sem atenção concentrada. A postura distraída, que Walter Benjamin atribuiu ao espectador de cinema, é a norma para a audição atomizada, pois esta é suscetível de ser conduzida pelos flashes, reforços cromáticos, acentuação de estilo, momentos individualizados, motivos melódicos hiper-sensuais etc., dirigindo a audição de modo a substituir a exigência objetiva da música pelo prazer de manipulá-la sem compromisso com sua estrutura própria. O que não corresponde à capacidade média de leitura musical nem sequer é oferecido, reforçando-se cada vez mais a identidade entre música e ouvinte, sendo isso a chave para a ideia de Adorno de a música de cultura de massa já vir ouvida, de forma análoga a como a mulher em uma foto pornográfica já vem desejada: a primeira é composta antecipando todos os mecanismos de tradução subjetiva, e a segunda ultrapassa toda dúvida do desejo por ela.

Se a atenção dispersa significa uma degeneração na música séria, por outro lado na música de massa já não há nada a ser degenerado, pois tudo segue cânones quase matemáticos do que deve ocorrer em cada momento, de acordo com fórmulas de sucesso já consagradas. Elas fazem convergir a atenção para toda espécie de efeito de superfície, renunciando quase completamente ao esforço de uma lógica de constituição própria de cada obra. Um desses elementos especialmente atrativos é a materialidade do som, do timbre dos instrumentos, levando o ouvinte a se interessar pela cor específica da instrumentação, que substitui a composição musical propriamente dita. Esse comportamento também possui características infantilizadas, pois ressoa a preferência das crianças pelo que é cromaticamente saturado (e adocicado). 
Esse complexo de coisas não garante uma consciência progressista do valor do fato sonoro individual, não significa a abertura a novas cores, timbres ou sons. Isso se dá porque toda particularidade na cultura de massa somente existe e funciona para reafirmar um esquema prévio bastante rígido. Elementos sonoros substancialmente novos são tachados de intelectuais, cerebrais, frios, precisamente porque advogam a autonomia de uma racionalidade alheia ao que já é demandado pelo espectador ${ }^{21}$. 0 elemento particular da cultura de massa é tão-somente uma negação tanto do significado da individualidade sonora em sua autonomia, quanto da totalidade construída através da tensão entre os elementos singulares ${ }^{22}$.

O gosto com essa particularidade previamente domesticada contém uma ambivalência constitutiva, pois o prazer se transforma facilmente em fastio, em asco e repulsa tão logo seu charme inicial se esgote. Apesar desta oscilação constante, os espectadores continuam a demandar esse mesmo tipo de produto, uma vez que sua demanda já é, por si mesma, um desvio: o próprio desejo é um fetiche, de modo que o consumidor gosta de gostar da música, deseja desejá-la. Assim, tudo o que é oferecido se transforma em signo do que deve ser apreciado, consistindo quase em uma ordem, em um imperativo socialmente estabelecido e individualmente confirmado.

O infantilismo da recepção possui seu correspondente na produção da obra também nos diversos erros composicionais, como a condução ilógica de vozes, o uso sistemático de quintas e oitavas paralelas etc. (Segundo Adorno, no conjunto das pessoas que trabalham para a realização da música, os arranjadores são quase sempre os de maior conhecimento técnico: quem compõe a linha melódica mais destacada é normalmente amador ou não tem formação musical séria.) Mesmo que os erros não sejam produzidos intencionalmente, são deixados devido a um princípio de recepção muito bem estabelecido, a saber: ressoar a linguagem infantil, em que todo tropeço, incompletude, elipse, confusão de letras, palavras e sílabas ("bicoto", "gugute", "bibi", "titia" etc.) indica um excesso sentimental que usa e abusa do material linguístico. A

21 Adorno abordou essa crítica ao caráter intelectualista do dodecafonismo na primeira parte da Filosofia da nova música.

22 Tal anulação do particular e do todo pela cultura de massa foi tratado de forma incisiva no capítulo "Indústria cultural" da Dialética do esclarecimento. 
linguagem, tanto das palavras quanto a musical, é por assim dizer inundada com o desejo de proximidade, de trânsito íntimo e descompromissado. Quanto mais se mutila pelos erros composicionais, mais a música se torna maleável a essas trocas afetivas. A consequência é que os ouvintes tendem, ao longo do tempo, a perceber a música de cultura de massa como muito mais "natural" do que todas as que seguem os princípios tradicionais de composição; estas tenderão a soar artificiais, secas e distantes dessa apropriação hiper-saturada de emotividade.

Outro procedimento bastante recorrente é o da citação: desde leves semelhanças de alguns motivos e células rítmicas até repetições explícitas de grandes sequências melódicas, as músicas de cultura de massa praticam duplicações e rebatimentos indefinidamente reiterados. O princípio geral é o da familiaridade, da acomodação do ouvido não apenas ao que já foi escutado, mas sim ao próprio ato de gostar da repetição como tal. Toda música deverá obedecer ao princípio do chiclete: deverá ser mastigada e ruminada até perder completamente seu sabor, quando então a única fonte de prazer será o próprio ato de mastigar.

\section{A ilusão de autonomia: a pseudo-atividade}

Embora vários críticos à leitura adorniana da indústria cultural denunciem a concepção de uma total passividade dos consumidores, Adorno não se ilude com uma visão totalizante nesse sentido. Embora aquela crítica nos pareça adequada em certo plano de análise, como já apontamos, é preciso considerar que Adorno focaliza e ressalta a importância de determinadas facetas da atividade por parte do consumidor. A questão, para o filósofo, reside no fato de o poder do sistema da indústria cultural ser grande a ponto de o que escapa a uma mera atitude passiva tornar-se uma pseudoatividade. O primeiro exemplo dessa absorção da faceta ativa do consumidor é o do entusiasta do jazz, com seus gestos convulsivos, eletrizados, frenéticos. Tal atitude representa mais o gozo com a descarga motora dos afetos, mantendo-se na superfície da violência e do frenesi. Seu conteúdo consiste na vivência do êxtase, não apenas demonstrado, mas reduzido a sua própria materialidade. Pode-se dizer que o prazer do entusiasmo está mais no entusiasmar-se, no preenchimento material da atitude de se 
entregar de corpo e alma a uma ritualística, do que na fruição da coisa como tal. Há algo de tribalista e de animalidade nas danças, como índice de negação da cultura por regressão deliberada, usufruída como recusa de sofisticação.

Todo esse ritual extático, porém, obedece a essa redução em virtude de sua pobreza mimética, de seu vínculo eternamente circular para com imagens: de sensualidade, de juventude, de felicidade, de revolta etc. Cada gesto de alegria tende a ser a caricatura do desejo de ser alegre, tanto no sentido de ser uma duplicação rebaixada, quanto uma ridicularização de uma alegria alcançada por direito próprio. Isso é produzido, não por uma total vitória da ilusão sobre o senso de realidade, mas sim pelo constante exercício parcial deste último, que leva sempre o indivíduo a praticar uma zombaria de seu direito não apenas à felicidade, tomada como um ideal abrangente, mas até mesmo de um prazer sexual digno do nome. O gozo é tendencialmente traduzido na eloquência, no brilho, nas cores e no barulho de todas as preliminares eternamente excitantes, mas cuja estimulação serve, considerada no plano social geral, à negação da sexualidade.

Aquele que mais bem corporifica a pseudo-atividade é o hobbysta, quem se deleita com as mais diversas bricolagens eletrônicas, gastando seu tempo e sua libido na manipulação indefinidamente circular e auto-satisfatória dos gadgets e parafernálias eletrônicas. Ele se sente bem por fazer parte do universo tecnológico, produzindo por seu próprio esforço minúsculo e artesanal quase tudo que já pode ser comprado pronto.

A conjugação máxima da inércia do sistema e da individualidade autoafirmadora é representada por quem age como se improvisasse, como se tirasse de sua própria cartola as idiossincrasias libertadoras perante o sistema, mas que, na verdade, confirmam todos os esquemas prévios definidores da lógica das diferenciações milimétricas. Trata-se do ideal supremo de adaptação bem realizada, quando a infelicidade da submissão é suplantada pela percepção de si como agindo de forma não apenas natural, mas desleixada, nonchalant, celebrando o supremo conformismo através da alegria descompromissada de se esquecer de si próprio. 
O entusiasta e hiper-ocupado com a cultura dos meios técnicos codifica a adaptação resignada ao sistema, demarcando o espaço da despolitização generalizada a que se submetem os ouvintes regressivos. Se estes representam algum progresso, trata-se da negação sistemática da consciência da negatividade inerente ao vínculo entre indivíduo e sociedade, produzindo sua acoplagem perfeita. A habilidade de consertar qualquer aparelho técnico demonstra a consciência do significado de tirar proveito de seu espaço na totalidade do sistema, simultâneo à satisfação de não ser um mero espectador passivo de toda a engrenagem, traduzindo sua disponibilidade de autotransformação em uma espécie de engrenagem autônoma. Desse modo, a indústria cultural produz uma pasteurização generalizada da consciência política, unificando progressistas e reacionários no espaço do frenesi de uma pseudo-atividade constante. Nesse meio, toda inovação técnica será suspeita de ser um progresso regressivo, ou seja, de acelerar a depravação da cultura e contribuir para barbárie.

A busca incessante por acolhida nos refúgios do sistema é acompanhada pela consciência masoquista de toda segurança ser meramente provisória, instável, cobrando seu preço exorbitante a qualquer momento. A adaptação a essa circunstância significa a renúncia a si mesmo como diferente do sistema, demandando a cada passo o ajuste à promessa de ser mais novo que algo assim proclamado há uma semana. Nesse momento, entra em jogo a clássica percepção do quanto o pseudomoderno, o atualizado, envelhece instantaneamente, pois é constituído por uma consciência abstrata, sumamente parcial e auto-ilusória do presente e da presença: trata-se de um novo apenas por diferença abstrata, por sua pura materialidade que preenche momentaneamente a vertigem de um tempo cuja essência é a de não possuir nenhuma, tragando na nulidade de seu devir toda pretensão a uma modernidade digna do nome.

Este pseudo-novo, na verdade um já-quase-velho, caracteriza em uma contração temporal absurda a audição regressiva, pois é necessário recalcar incessantemente a consciência de a música de massa atual ser uma fraude, um engodo, um blefe. Em virtude disso, o ouvinte regressivo está sempre prestes a se 
enfurecer: com o que lhe é oferecido e com sua própria atitude resignativa, que denuncia seu êxtase com o objeto como sendo na verdade mera atuação.

O que haveria de progressista na música de massa? Adorno aponta e critica dois aspectos: o caráter lúdico e a suposta liberdade técnica. O primeiro entraria no lugar da seriedade do valor de culto, aurático, da arte, momento em que a aparência de totalidade circunspecta do objeto cederia espaço a uma dimensão mais concretamente palpável, ou seja, ao puro entregar-se à coisa em sua materialidade tangível. Esse desnudamento da transcendência, porém, é apenas aparente, pois a diversão no capitalismo tardio é uma obrigação, um ritual praticado sistematicamente nas frestas do sistema do trabalho. De forma análoga a como o esporte enquanto espetáculo de massa não é "jogo" na acepção do termo para nenhuma das partes os jogadores não "jogam", pois seguem regras estritas em função de um compromisso financeiro, de trabalho, cônscios da seriedade de serem "profissionais", e os espectadores tampouco, pois apenas assistem e se contorcem em suas emoções, tomando parte no jogo por procuração - , o lúdico na música de massa é apenas a capa ideológica para a acomodação ao leque de atividades frívolas e de escape à seriedade do trabalho, pautadas de forma enfática pelos códigos de pertencimento a camadas e grupos sociais, cuja obediência é tão duramente mantida quanto a do trabalho.

No segundo aspecto, da técnica, não há progresso tanto em virtude de os aspectos de fluidez dos timbres e da liberdade rítmica, especialmente exemplificada pela síncope, já se encontrarem na música séria, quanto pelo fato de tais características perderem seu sentido ao serem deslocadas de seu contexto onde possuem sua legitimidade. "Progresso" ou "regressão" técnicos se medem de acordo com a totalidade em que são inseridos, e na música de massa cada elemento técnico é não apenas esvaziado de conteúdo, quanto ainda ressaltado de forma fetichizada, substituindo o poder de articulação contextual pela evidência, brilho e repetição exaustiva. Nesse momento, a "perfeição" com que se utiliza um "achado técnico" é índice de sua falsificação, pois tende a substituir o conjunto articulado de todas as partes pelo glamour de sua singularidade. 
A positividade da música de massa, ou seja, sua exposição ostensiva, vitalidade rítmica, florescência de timbres, abrangência de público - tudo considerado uma resposta a certa consciência culpada dos intelectuais por sua distância ao público - , configura, porém, uma negatividade, uma regressão perante a única via aberta: a crítica. A verdade em um sistema que a cada dia se mostra mais abrangente e totalitário somente pode se dar negativamente. Tal como do sublime ao cômico somente um passo é necessário, a música de massa é invariavelmente acompanhada da sombra do deboche e do escárnio que denuncia a incompossibilidade entre o caráter lúdico da música e todo o esforço feito para realizá-la. A música massificada vive em meio a contradições desse tipo, sendo o rádio um meio especial para perpetuação de tal estado de coisas, limando a música de sua seriedade, aplainando a contradição entre o estético e a vida, ao mesmo tempo em que insiste tenazmente para afirmar o musical como elemento imperioso, destacado, enfático da vida cotidiana.

A música séria, por outro lado, não consiste, mesmo em seus melhores momentos, apenas na utilização consciente de materiais musicais avançados, "absolutamente modernos". As composições de Gustav Mahler são um exemplo de um aproveitamento progressista de materiais gastos e antiquados. De forma próxima a Bach - a quem se chamou de superado em sua época -, Mahler alcança uma paradoxal liberdade com o que já está saturado pelo uso ordinário, fazendo surgir o novo não "do zero", a partir do menor elemento do material musical, mas por sobre as ruínas da música depravada e fetichizada. Isso mostra a imbricação dialética entre progresso e regressão, presente, de outra forma, nas músicas de Schönberg, Alban Berg e Webern: estas não simplesmente ignoram o caráter regressivo da cultura, mas sim codificam a angústia perante a alienação do indivíduo, seu isolamento, seu caráter desesperado de solidão em meio ao incompreensível. 